\title{
Excavating our Shadows in Teaching Through Narrative Analysis
}

\author{
by \\ Rochelle Gagnon
}

As he walked through the door that first day I thought, "Oh, God! Would you look at what I end up with this year!" His previous teachers had already prepared me well for his coming, as they had dutifully filled my head with tales of mischief, grief and horror from their own encounters with him. His name was Donald. He wore an earring, his hair short on top had a long outgrowth trailing serpent-like down his back; the braid nearly down to his buttocks. He was a SLOB. I'm sorry but there really is no other suitable word to describe him. Overweight, with dirty ripped clothing, not the "trendy" slobby but more like the "poor" slobby. He looked at me from the doorway in disdain not sure whether he was actually going to come in or change his mind and turn away. I'm sure the look of disbelief radiating from my eyes had something to do with his hesitation.

He finally lumbered in and found a desk near the back of the class. "Hah!" I thought, "You won’t be sitting there long, causing trouble where I can't see you!" Actually I didn't think he'd last long in the class at all, more likely he'd be spending his days down at the office or at home if I had my way about it. "Maybe he'll be sick a lot this year," I thought. Although I knew very well that the "bad" ones rarely missed since their parents couldn't stand to have them around either.

Things went down hill from there. He drove me crazy. He beat up anyone who looked at him the wrong way (and most times ANY way was the wrong way!). He constantly swore at me and the other students and during class discussions he was never too shy to entertain us with stories of how he had stayed up the night before until 2am playing some video game or another, while his father lay on the couch too drunk to get up. As time went on I began to sweat any time he opened his mouth.

Add to all of this misery, the fact that I was teaching in a French immersion setting and I actually had to get this student to speak, or in his case, swear, in another language. I was to have absolutely no luck in this endeavour as he flatly refused to either speak French or complete any assignments that I handed out. Now, as anyone who has taught in French immersion well knows, there is one unwritten rule that must never be broken and that is that the teacher is NEVER to speak English to the students. Even if this rule is rarely stated openly, every French immersion teacher knows implicitly that if he or she is ever "caught" speaking to students in English when it is not the English Language Arts period, that he or she will be seen as a "bad" teacher; substandard in some way. Since most would rather be seen as "good as well as competent teachers," many then are careful not to break this rule, myself included. But what to do then with someone like Donald who played at being "deaf" anytime I spoke to him in French?

I dealt with it by either ignoring his very existence or when he was particularly obnoxious, resort to yelling and threatening - not that it ever did any good - since my voice simply bounced off his bulk and flew right back at me. I endured this situation steadfastly until one day Donald finally became the "straw" that broke my back! I really don't remember what he did, I'm sure it was nothing worse than his usual antics but that day it was simply too much. I felt a wave of rage sweep up from the tip of my toes and come blazing up through my body to settle behind eyes, seething with pent up anger, frustration and yes, even hate. From behind my great desk I prepared my assault as I watched him gear up to retaliate in kind - when all of a sudden, a tiny little thought wiggled its way into the eye of the storm in my head. It said quite clearly, "You will lose." It stopped me in my tracks. I turned in my mind to listen, and on it went, "If you continue down this path, you will lose. He has fought this same battle many times and has won against better opponents than you." "Hum!" I thought, "Since I really don't like to lose, maybe I need to take some time to reconsider my position here."

All of these thoughts chased through my mind in a fraction of a second but in that moment something opened inside of me. I began to consider that maybe I had choices other than losing control and fighting him. This tiny opening in my self led me to question my own involvement in the problems I was having with this student. 
"Was it possible," I thought, "that my own behaviour was contributing to Donald's wilfulness and belligerence? How would changing my behaviour change the situation itself?" These questions raced by so quickly that I was barely able to process them as I sat there in the heat of the moment.

I often wonder what my face must have looked like while I went through all these silent machinations in my mind? And what Donald must have thought when I simply remained in my seat and said nothing to him. He must have been bewildered by this sudden retreat or maybe just relieved that he had unexpectedly escaped the need to engage in another of life's battles.

I did nothing right then. It was not until a few days later, once I had had time to reflect on what had happened in my own mind, that I changed my way of being with this student. The first thing I did was to ask him to place his desk next to mine. I'm sure he saw this as a form of punishment but since he was so used to being punished he didn't put up much of a fight. The second thing I did was to stop talking French to him and from that moment on we were to converse in English only. The third thing I did was to no longer ask him to complete ANY assignments for me. While the others worked assiduously at their desks he was free to simply sit beside me and talk or doodle or do whatever he chose, it was up to him. I never explained any of this to him or to the other students in the class. I simply DID it. I talked to him and he talked to me quietly while I planned or corrected assignments at my desk. If the other students found this special treatment of Donald odd they never said. I always felt they somehow understood that he was different from them and therefore needed to be attended to differently.

I remember little now of those conversations with him seated next to me. For the most part they weren't earth shattering, just two people getting to know each other. His mother had told me in confidence at the beginning of the school year that Donald's father beat her regularly and that she had tried to escape to another city with her son but that he had found them and brought them back. Tearfully she explained that she could never leave because he had threatened to kill her the next time she tried. I didn't know what to say, I don't suppose there is much one can say to such a horrific situation. What her candour did do, was to make me aware of some of the hardships Donald had had to face in his family life and with time the more he shared of himself and of this life, the more I softened to him.

One conversation that I do remember was when he shared with me his disappointment at not getting what he had hoped for that Christmas. It seemed that his father had gone out of his way to get him something he knew he wouldn't like. I told Donald that he should tell his father how he was feeling so that he would know that his actions had hurt him. (I feel sick every time I think of this conversation).

The next day when he got to class, Donald told me he had done exactly as I had counselled him to do and had told his father of his feelings. His father's response had been to strike him down in a fit of rage. I was dumbfounded. Speechless. But mostly I was incredibly humbled. I realized how much he must have trusted me in order to get up the courage to tell his father of his feelings. The risk he took because of my thoughtless and off the cuff counselling was more than I could face. I said the only thing that I could, "I am so terribly sorry." Needless to say I have NEVER again given such arrogant and mindless advice to a student. I was thrown from my pedestal that day and I truly hope that I will never be so caught up in my own self-importance to gravitate to that spot again. It was a grave mistake, one that I will never forget.'

I don't know how long Donald sat at my side. Weeks perhaps. But at some point he did reclaim his place in the class although the bond between us never let him stray too far from me. His behaviour in the classroom changed drastically over the next few months. He no longer fought so much, he was much more respectful of both me and the other students in the classroom. He got rid of that scraggly looking "ponytail." But by far the most incredible change was that by the end of that school year, Donald spoke more and better French than most in the class. He never became an A student, but he completed his assignments to what I believe was the best of his abilities. He was changed but more importantly I was changed. 
I left that school at the end of that year, therefore I was never to know what became of that darling little six year old that I came to love and cherish so. I can only hope that the beginning of grade two was better than his first experiences had been with me. When faced with the inevitable difficulties that I'm sure life has thrown Donald, perhaps he has been able to gather strength by recalling a time of caring, where he sat beside a teacher who was able to "see" through all his posturing and defences to the scared little boy who so badly needed someone to believe in him. It still amazes me today that I could have gone from a state of such anger and hatred to one of great understanding and love. It was nothing short of miraculous. I will always be proud that I had the courage to brush aside the fears I had of being judged and truthfully perhaps even "fired" for the unorthodox ways I chose to deal with this student. I know now that my decisions were intuitive not logical, I didn't weigh the pros and the cons I just "acted" and the results were well worth the risk.

But I did not tell this story simply to tell a story or to entertain. As Fowler (2002) says, "In narrative and interpretive educational research, stories themselves are not enough." I am telling this story because of what it made me "face" in myself not only as a teacher but as a human being as well. Donald brought me to the wall, and forced me to reflect on my practice at a deeper and more meaningful level than I ever had before. This situation had little to do with the fact that I taught in a French immersion setting but more to do with the "unwritten rules" that exist in all schools and the "unconscious" adherence of teachers to these rules. My own faithfulness to these did not allow me to go deeper into myself to see what was really going on and to take ownership for the part that I was playing in the difficulties with this student. Fowler (2002) explains that narratives "serve to ground a reflective practitioner who is able to call one's shadow (Jungian interpretations of that term) to "heel," to leave practices of unhealthy transference outside the door and to dwell in embodied action with one's students." What I lived with this student enabled me to meet my shadow side. This encounter was by no means an easy or pleasant experience but through it I became a braver as well as better teacher and person.

\section{The Shadow}

The purpose of this article is to shine my consciousness across the page in order to dance with my shadows as they appear throughout this narrative. I do not want to fear these less than sparkling sides of myself but intend to face them head on. Above all else I seek Truth, in myself as well as in others. By identifying the different shadow themes that emerge from this narrative, I hope to help other teachers recognize the shadows that lurk within them. Recognizing our less than perfect selves enables us to not "buy" into assumptions or hidden rules that lead us as teachers to act out the fear of not being valued as "good enough" educators. When we do not seek perfection, but Truth we free ourselves to "teach who we are" (Palmer, 1999, p.1.)

It is important that readers have a clear understanding of what the shadow is. To clarify, Adams \& Zwieg (1991) give the following description,

"Each of us contains both a Dr. Jekyll and a Mr. Hyde, a more pleasant persona for everyday wear and a hiding, nighttime self that remains hushed up much of the time. Negative emotions and behaviors - rage, jealousy, shame, lying, resentment, lust, greed, suicidal and murderous tendencies - lie concealed just beneath the surface, masked by our more proper selves. Known together in psychology as the personal shadow, it remains untamed, unexplored territory to most of us." (p.xvi)

Telling this story now has enabled me to reflect deeply on my own dark self which has allowed me to identify 6 overall shadow themes that course through this teaching episode. It is my hope that teachers will be able to identify with these themes and then to look to their own experiences with students in the classroom in order to analyse how they live out their own darkness in teaching.

\section{Shadow Themes}


1. Judgment: Even before that little boy had entered my room I had judged and labelled him as a trouble maker. I drew this conclusion based solely on what other teachers had told me - I never even thought to question what they had said - I simply took it as fact. Donald knew he was being harshly judged the moment he saw me, I had it written all over my face, I didn't need to say a word.

2. Cruelty: I don't like thinking of myself as cruel but if I am to be brutally honest that's exactly what I was. I did not accept Donald into the classroom like I did the others. I expected him to fail and to be a "bad" student and these negative expectations were certainly fulfilled. I didn't intentionally set out to be so mean-spirited but my negative thoughts about him seeped out of me and into my actions. Students are neither stupid nor blind, Donald knew immediately what I thought of him - he understood that he had already been tried and found guilty therefore there was no need to even attempt to be different than what I already expected he would be. I'm sure the reader was very aware of my cruelty simply by the words I used in the narrative: "bad ones," "slob," "poor," "dirty" and other things such as hoping he would be sick a lot that year, or deciding before he had done anything wrong that he would be spending time in the office, all reflect my cruel intentions toward this student. I am not proud of this and it is difficult even now to look closely at my behaviour but today I realize that these uncomfortable feelings indicate that I am nearing the land of shadows and that it is only when I stay with this discomfort that healing can occur.

3. Fear: $\quad$ I know that a big part of the problem was my fear of this student. My fear sprang mostly from the unsolicited comments of my colleagues who thought they were doing me a favour by warning me of what was in store for me with this student. It was no favour because it blinded me for a long time to what was in front of me. My fears also sprang from Donald's uncontrollable behaviour. The things he said in front of the other six year olds was enough to put me into cardiac arrest but I know now that he was simply being honest about what went on at home. As long as I let my fear of what I "thought" he was control me, it remained impossible for him and I to have a relationship.

4. Lack of I did not have the courage to change my ways for a long time because I feared what others courage: would think of me. I was scared of being rejected, shunned or even worse fired because by making the choices I finally made, I knew I was breaking many of the "unwritten" rules. By pushing me to the wall, and giving me very few choices, Donald enabled me to find the courage I needed in order to deal with him in a different, more humane way and for this I will always be grateful to him.

5. Rage: I have rarely felt the kind of rage I felt with this student. I could barely see straight when he was around. I was so frustrated by his behaviour that my sense of powerlessness would manifest itself in yelling matches and threats that got me exactly "nowhere" with him but simply led to further frustration. I realize today that I wanted to "control" him so that my job would be easier. He would not allow me to do this, which I can now understand since I'm sure he was controlled enough at home. He fought a valiant battle which he finally won. I'm glad he did because he could easily have lost himself to my rage.

6. Arrogance: I really did believe that I knew it all back then. I mean what could a bunch of six year olds really know, right? Today, I believe they know a lot. They never questioned what I did with Donald, they knew. This alone should have been proof that I was on the right track They were wiser than I but my arrogance kept me from seeing it. Also as I stated in the story, my delusional belief in my psychotherapeutic abilities and my thoughtless counselling certainly came home to haunt me. I admit wholeheartedly that I was arrogant in counselling this child to do something that ultimately put him in danger. It's unfortunate that this arrogance had to 
be knocked out of me at his expense but it was a valuable lesson, one that I will never forget.

\section{Repercussions of the Shadow in the Classroom}

Johnson (1991) tells us that, "unless we do conscious work on it, the shadow is almost always projected; that is it is neatly laid on someone or something else so we do not take responsibility for it"( p.31). I would say this is exactly what happened to me in that grade one classroom. I could not change the situation with Donald because I believed that it was "him" who was the problem. It was not until that moment of grace where I was able to turn the mirror of responsibility in my direction that I had a hope of changing things. In teaching, the student is very often the "scapegoat" for everything that goes wrong in the teacher's life. I have heard few teachers, during morning coffee in the teachers' lounge, own their own bad behaviour with students. What we do hear is griping about this "awful" student or that "terrible" thing he or she did, but rarely do we hear about the "terrible" things that teachers themselves do in the classroom. I for one NEVER talked about this episode with any other teacher - it would have been unthinkable for me to put myself in that kind of vulnerable position. This is one of the reasons why I am telling this story now - as I came to realize that I could not proceed with my own shadow work until I managed to "excavate" elements of my dark self by owning what I had done to myself as well as to others. Whitmont (1978), in The Symbolic Quest supports this idea when he writes,

"There is in fact, no access to the unconscious and to our own reality but through the shadow...Hence no progress or growth is possible until the shadow is adequately confronted and confronting means more than merely knowing about it. It is not until we have truly been shocked into seeing ourselves as we really are, instead of as we wish or hopefully assume we are, that we can take the first step toward individual reality" (in Adam \& Zweig 1991, p.16).

Adam \& Zweig (1991) go on to emphasize that, "once we begin to develop awareness of parts of the unconscious personality, then the shadow takes on an identifiable and personal form, which initiates the process of shadow work" (p.6). Therefore, it was not enough that I changed in the classroom. I needed to have the courage to admit to my bad behaviour, in other words really "dig" into this teaching episode to understand at a deeper level who I was and am as a teacher. The result of this in-depth analysis has been to rid me of the nagging feeling of "guilt" that I carried around for years, wondering if what I had done was indeed the right thing to do with this student. I understand now, as the above mentioned quote states, that I could only "excavate" this guilt by walking through the shadow, admitting to myself and others that while my interactions and thoughts in regard to this student had been inappropriate, the way I chose to rectify the situation was in fact, the "right" thing to do in "that particular circumstance."

I am certainly not recommending that all French immersion teachers begin speaking English to their difficult students, but I believe that teachers need to be aware that sometimes the ways in which they choose to deal with students come from their shadow and are therefore not healthy choices when confronted with the fragile selves of even the most difficult students. At times, teachers need to "break" the rules in order to do what is best for students in particular situations. Teachers who are faced with these types of difficult decisions will only choose the courageous path if they are truly aware of their darker sides since many times the "best" way to deal with students lies on the other side of the shadow. Teachers telling their stories with honesty is certainly one way of confronting the dark elements of the "self," since the courage that this takes is a powerful antidote to the fear surrounding and protecting the shadow.

Author Marguerite Hansen Nelson tells us "stories based on actual experiences have the potential to be an initiation to and exploration of the wisdom, beliefs, and values of the community and culture of teachers" (p.110). She continues, stating that "it would be ideal if more teachers would write about their own work, but the limitations of time and energy deny that prerogative to all but a few, and those who have told their stories 
in popular books have not often been recognized by scholars (Barone, 1992; Schubert, 1990, in Hansen Nelson 1993 p.5). I would like to see this change. Researchers need to guide teachers in telling their own stories not simply as a form of "data collection" but as a way of creating a space of "non-judgment" that would allow educators to "excavate" and "deal" with their shadow sides. There is far too much "pretence" in teaching. Teachers pretend that they are "always" patient, caring, loving, altruistic and fair because they fear the repercussions of not being seen as all these things. While this may be due in part to bad publicity and a general lack of support by the public for the education system, we all need to realize that first and foremost teachers are "human." No, they are not perfect and yes as everyone else on the planet, they do have a dark side.

What needs to be remembered is that hiding or running from the dark side only makes it more powerful. Jung reinforced this idea when he stated in 1938, "Everyone carries a shadow, and the less it is embodied in the individual's conscious life, the bleaker and denser it is. If an inferiority is conscious, one always has a chance to correct it...but if it is repressed and isolated from consciousness, it never gets corrected" (p.131).

Therefore it is not by pretending that we, as teachers, are always paragons of good behaviour that we will escape the consequences of the shadow, for this would be impossible. Teachers need a forum and safe place where their shadow stories can be told so that they can begin their own process of shadow work. This "coming to terms" with the dark self is what will prevent teachers from "acting out" their dark side in the classroom by unconsciously projecting their own unresolved issues onto their students. By creating a place in educational research for these types of stories we can only make schools healthier as well as happier places for both teachers and their students.

\section{Conclusion}

Something truly wonderful happens when one is freed from a lurking shadow, as Johnson (1991) explains, "If you can touch your shadow - within form - and do something out of your ordinary pattern, a great deal of energy will flow from it" (p.47). It is this energy that I now seek, hence in a difficult situation, I try always to look to myself first by asking questions like, "What is my part in this?" "How will this situation change if I change my own behaviour?" "Is it the student or is it me?" "If it is I, what part of me is in shadow?" The answers are not always easy to face but I now know that it is this level of honesty that allows teachers to see themselves as courageous and truthful and will ultimately result in a more peaceful and joyous classroom atmosphere. As Palmer (1998) states so eloquently,

"Teaching, like any truly human activity, emerges from one's inwardness, for better or worse. As I teach, I project the condition of my soul onto my students, subject, and our way of being together. The entanglements I experience in the classroom are often no more or less than the convolutions of my inner life. Viewed from this angle, teaching holds a mirror to my soul. If I am willing to look in that mirror and not run from what I see, I have a chance to gain self- knowledge - and knowing myself is as crucial to good teaching as knowing my students and my subject (p.2).

To all those brave enough to commence the excavation of their shadow, know that you will be a better teacher and person for it. To no longer live a life of deception invites one to begin a journey of self-discovery and inner learning that allows in the end, students as well as teachers, to be who they truly are instead of who they think they ought to be. It is important as teachers never to forget that we are surrounded everyday by Truth and Light since young people are always closer to these elements than we as adults are. Therefore, teachers look to your students, for it is near them that your Darkness lurks but it is also through them that you can discover how to teach as well as live from your own Inner Light.

\section{Notes}

In order to deal with my own feelings as well as my ethical responsibilities, I sought out our school counsellor who took care of notifying the appropriate people in regards to the abusive situation and at the same time 
became an important source of strength and support for me as a teacher. I'm not sure how I would have survived that year without him. In order to protect the student's anonymity in this story, his name has been changed. The incident is one that happened many years ago therefore all that were in this classroom have now reached adulthood and are therefore unlikely to recall this incident. As well I have refrained from directly quoting the student or any other people involved in this teaching episode

\section{References}

Adams, J. \& Zwieg, C. Meeting the Shadow - The Hidden Power of the Dark Side of Human Nature. J.P. Tarcher, Los Angeles, 1991.

Fowler, Leah, C. A Curriculum Of Difficulty And "The Anger In Our Miss Maple: The Story and the Commentary. Journal of Language and Literacy, 3(2), 2001. [available online: http://educ.queensu.ca / landl/].

Johnson, Robert, A. Owning your Own Shadow, Understanding the Dark Side of the Psyche. Harper San Francisco, 1991.

Nelson Hansen, M. Teacher Stories, Teaching Archetypes Revealed by Analysis. Prakken Publications, Ann Arbor, 1993.

Palmer, Parker, J. The Courage to Teach, Exploring the Inner Landscape of a Teacher's Life. Jossey-Bass Publishers, San Francisco, 1998.

Read, H., Fordham, M., Aldler, G. The Collected Works of C. G. Jung: Psychology and Religion (1938). (12). Princeton University Press, Princeton, N.J., 1953 - 1973.

Whitmont, E. C. The Symbolic Quest. Princeton University Press, Princeton, N.J., 1978.

\section{Author Biography}

Rochelle Gagnon completed her Master's degree in Education with a specialty in the study of Languages and Cultures at the Faculté Saint-Jean, Edmonton, in December 2001. Her research project was entitled "A Framework for the Paradoxical Teaching of Writing : Succeeding with Writers' Workshop" (translation). She has taught for the same school district for the last 12 years but is currently staying at home to care for her 4 boys. 